\title{
Dinheiro e crédito em David Harvey: comentários críticos
}

Money and credit from David Harvey's work: critical comments

Argent et crédit chez David Harvey: commentaires critiques

Dinero y crédito en David Harvey. Comentarios críticos

\section{Maurilio Lima Botelho}

\section{(2) OpenEdition}

\section{Journals}

\section{Edição electrónica}

URL: http://journals.openedition.org/espacoeconomia/1760

DOI: 10.4000/espacoeconomia.1760

ISSN: 2317-7837

\section{Editora}

Núcleo de Pesquisa Espaço \& Economia

\section{Refêrencia eletrónica}

Maurilio Lima Botelho, « Dinheiro e crédito em David Harvey: comentários críticos », Espaço e Economia [Online], 6 | 2015, posto online no dia 24 setembro 2015, consultado o 01 maio 2019. URL : http://journals.openedition.org/espacoeconomia/1760; DOI : 10.4000/espacoeconomia.1760

Este documento foi criado de forma automática no dia 1 Maio 2019.

(c) NUPEE 


\title{
Dinheiro e crédito em David Harvey: comentários críticos
}

\author{
Money and credit from David Harvey's work: critical comments \\ Argent et crédit chez David Harvey: commentaires critiques \\ Dinero y crédito en David Harvey. Comentarios críticos
}

Maurilio Lima Botelho

\section{Introdução}

1 David Harvey é normalmente visto como um teórico das questões urbanas do mundo contemporâneo, um estudioso das transformações gerais na estrutura urbana, um autor voltado à tematização da dimensão espacial das relações capitalistas e intérprete das novas relações geopolíticas internacionais. Para cada uma dessas linhas de reflexão poderiam ser destacadas obras fundamentais de Harvey que tiveram impactos no mundo acadêmico, como A Justiça Social e a Cidade, A Condição Pós-moderna, Novo Imperialismo ou História do Neoliberalismo. Entretanto, a obra principal de David Harvey, Os Limites do Capital , contém não apenas o embrião de cada uma dessas abordagens como poderia ser tomada ainda como uma das mais importantes obras de análise sobre o sistema de crédito. Teórico da geografia, David Harvey raramente é enxergado como um intelectual das questões econômicas mais complicadas e obscuras. Contudo, há em vários capítulos dessa obra fundamental uma análise cuidadosa e profunda da relação entre o sistema monetário e o sistema de crédito na economia capitalista. Poderíamos destacar ainda que no cerne da teoria espacial de David Harvey encontra-se uma teoria do capital financeiro que torna sua obra importante não apenas para a compreensão dos mecanismos geográficos de expansão capitalista como também para entender as minúcias de uma sociedade que levou a financeirização ao extremo.

2 Poucos autores notaram essa dimensão na obra de Harvey, pois quase sempre sua abordagem do sistema financeiro é vista como mero prolegômeno à teoria da 
urbanização. Mas é preciso notar que temos aí grandes contribuições ao estudo da relação entre moeda e crédito, entre dinheiro e capital financeiro e principalmente à análise da ficcionalização da riqueza. Isso foi observado por Fredric Jameson de modo muito pioneiro, ainda quando Os Limites do Capital era uma obra reduzida a poucos nichos de leitura da nova esquerda norte-americana. ${ }^{1}$ No Brasil, Leda Maria Paulani utilizou essa obra de David Harvey para tratar do capital fictício, reconhecendo aí contribuições na compreensão de como o sistema de crédito parece ser chamado para harmonizar problemas do capitalismo, mas na verdade acaba complexificando e ampliando suas contradições. ${ }^{2}$

3 É exatamente com o intuito de trazer parte dessa discussão para o primeiro plano que apresentamos a seguir as principais contribuições levantadas por David Harvey sobre o sistema de crédito. Nosso foco será a obra principal citada - Os Limites do Capital -, publicada originalmente em 1982, mas faremos uso, quando necessário, de outras referências que possam demonstrar a importância dessas reflexões ao longo de sua produção teórica. Mais do que reproduzir os argumentos principais da leitura do geógrafo, nossa intenção é desenvolver suas principais teses e ressaltar suas contribuições originais, destacar os autores e obras com quem dialogou e apresentar os desdobramentos de algumas de suas teses para a compreensão de nossa situação no capitalismo contemporâneo. Nesse processo, como ficará claro, nosso trato com as formulações de Harvey passa por um crivo crítico, já que muitas de suas idéias precisam ser problematizadas.

\section{Do sistema monetário ao sistema de crédito}

4 A teoria do valor de Marx é também uma teoria do dinheiro. 0 fato de que as mercadorias precisem se espelhar numa forma simples e comum a todas elas (a forma geral de valor) produz necessariamente a condição do equivalente geral que representa todas as mercadorias e por cada uma delas pode ser trocada (a forma dinheiro). o produto que funciona como o equivalente geral pode ser confrontado com todas as demais mercadorias como dinheiro porque antes foi confrontado como uma mercadoria. Portanto, dinheiro é mercadoria. Mas é uma mercadoria especial, que passa não apenas a se confrontar com outras mercadorias mas também a mediá-las, transformando-se em elemento central e aglutinador do mundo das mercadorias.

5 Como mercadoria, o dinheiro possui um determinado quantum de trabalho cristalizado em sua forma social. Dinheiro é, antes de qualquer outra coisa, a mercadoria capaz de servir como medida do valor - ao espelhar outra mercadoria, não reflete a natureza material desse produto, sua particularidade ou sua utilidade, mas simplesmente sua forma socialmente condicionada de trabalho despendido, isto é, sua generalidade enquanto resultado do trabalho abstrato. Dinheiro é a "forma necessária de manifestação da medida imanente do valor das mercadorias: o tempo de trabalho" (Marx, 1985a: 87).

6 Há uma complicação nessa primeira função do dinheiro. Embora seja a manifestação do valor, o dinheiro perfaz essa função apenas através de sua natureza particular, com sua expressão material direta. Como a forma geral de valor precisa ser o desdobramento de uma forma simples equivalente, portanto, uma mercadoria como qualquer outra, é apenas através de sua natureza corpórea que se exprime o valor de troca de outras mercadorias. Como o dinheiro é essa forma fisicamente metafísica em que a "existência funcional absorve, por assim dizer, a sua existência material" (Marx, 1985: 110), ao 
manifestar o valor das demais mercadorias, o dinheiro o faz empiricamente somente por meio dos padrões de preço. Embora seja a encarnação social do trabalho abstrato, esse quantum de trabalho é representado sob a forma de uma determinada quantidade de dinheiro, de uma determinada quantidade dessa mercadoria particular. Com a moeda metálica, isto é, o ouro ou a prata como as mercadorias que funcionam mais apropriadamente como dinheiro, como equivalente geral, a manifestação desse padrão de preço ocorre através de uma determinada quantidade física desses metais. Assim, funcional e materialmente, o dinheiro possui imediatamente duas funções: a de medida dos valores e de padrão dos preços. Duas faces da mesma natureza contraditória do dinheiro: sua face abstrata e sua face concreta, sua determinação funcional e sua determinação física, sua forma e a matéria que lhe exprime.

Uma série de questões complicadoras poderia ser apontada aqui, entre elas o fato de que já no princípio da reflexão de Marx sobre as categorias básicas do capitalismo (mercadoria e dinheiro) surge a diferença entre valor e preço, algo que só pode ser definido do ponto de vista da concorrência. A relação entre produção e a circulação de cada mercadoria (ou entre oferta e demanda), assim como a relação entre produção e circulação do dinheiro (oferta monetária e velocidade de circulação do dinheiro) ou, no fundo, a relação entre o conjunto das mercadorias e o conjunto do dinheiro, implica em variações na proporção física do dinheiro que acaba por impedir a identidade imediata entre o valor de uma mercadoria e o seu preço.

Como equivalente universal, o dinheiro funciona como medida de valores e fornece um padrão de preço contra o qual o valor de todas as outras mercadorias pode ser avaliado. Mas a realização desses preços depende de um processo de troca e, portanto, envolve valores de troca. A intervenção da troca converte uma relação necessária entre proporções de valor em uma "relação de troca mais ou menos acidental entre uma simples mercadoria e outra, a mercadoria monetária". Os preços de mercado desviam-se dos valores como resultado disso. 'Isso não é um defeito', insiste Marx, porque "as irregularidades sem lei" da produção e da troca de mercadorias, as perpétuas oscilações entre a demanda e a oferta, podem não possibilitar o equilíbrio exceto ao permitir que os preços flutuem em torno dos valores (EI: 242; EM: 244-247; EB: 324). ${ }^{3}$

Isso só demonstra que a categorias de Marx precisam ser encaradas como categorias em movimento e não tomadas analiticamente em si mesmas, pois elas só fazem sentido ao fim da exposição lógica, quando todas suas determinações estão postas e, assim, sua complexidade teórica se aproxima da complexidade real. ${ }^{4}$ Isso nos permite superar a aparência socialmente necessária intrínseca a esta sociedade em que os indivíduos surgem imediatamente como se fossem entidades dotadas de autonomia e de vontade, soberanos em seus próprios atos, socializando-se apenas secundariamente através dos objetos e do mercado. Porque a apreende como a aparência necessária dessa sociedade e não como mera falsidade, a lógica de exposição de $O$ Capital segue essa aparência, partindo do indivíduo isolado portador da capacidade de trabalho e de sua produção particular. Apenas com a circulação e os mecanismos de concorrência é que se torna possível compreender exatamente a forma desse individuo atomizado.

Portanto, a cisão inicial entre valor e preço só existe de um ponto de vista analítico, pois as mercadorias individualmente possuem apenas preço; sua existência como valor depende de sua realização através do processo de venda, quando o trabalho abstrato presente potencialmente em sua forma for capaz de representar realmente uma parcela da massa global de valor (apropriada por um capital em particular). Individualmente, isoladamente 
e sem realização, uma mercadoria não é capaz de representar valor algum. Toda mercadoria, para sermos rigorosos, é imediatamente representada em preço, sua manifestação empírica em dinheiro. Apenas através da realização no mercado é que esse preço representa a apropriação de uma parcela da "força conjunta de trabalho da sociedade" (Marx), apenas dessa maneira pode demonstrar que corresponde a "tempo de trabalho socialmente necessário". ${ }^{5}$

10 É importante destacar isso porque seus desdobramentos são complexos, causam uma série de incompreensões e os problemas daí decorrentes são cada vez mais atuais. Mercadorias produzidas em condições de produtividade baixa e com custos elevados segundo o padrão dominante acabam por cair fora do mercado, não são vendidas ou, se o são, acabam por não conseguir pagar seus próprios custos. Essas mercadorias mobilizam dinheiro, massa monetária em sua circulação, espelham-se em dinheiro, têm preço, mas são incapazes de acrescentar mais-valor à massa global de riqueza capitalista. 0 mesmo se pode dizer de mercadorias produzidas em condições de automação total ou quase total. Como são mercadorias provenientes inteiramente de meios de produção, produzidas por capital constante, por trabalho morto, não representam nenhum acréscimo de valor ao sistema, embora reproduzam o valor presente nos meios que lhe criaram (amortização dos custos). Essas mercadorias têm preço, podem ser comercializadas, podem retornar da circulação sob a forma de um quantum monetário, mas são inteiramente desprovidas de valor. Portanto, ainda que do ponto de vista do produtor individual elas apareçam como lucrativas, não representam nenhum acréscimo à massa global de valor, não são capazes de manter a reprodução ampliada do capital. É importante verificar, de imediato, essa relação entre preço e valor pois suas implicações são amplas, provenientes dessa diferença aparentemente banal e pouco importante entre medida de valor e padrão de preços. ${ }^{6}$

11 Além da função de medida do valor, o dinheiro realiza também a função de meio de circulação. Isto é, o dinheiro pode ser verdadeiramente o nexo mediador entre todas as mercadorias. Como é equivalente a qualquer mercadoria, um determinado produto pode se metamorfosear em dinheiro e, através deste, transformar-se em qualquer outro produto. Marx analisou em especial essa função aparentemente simples do dinheiro, principalmente o transtorno que provoca em toda a lógica social: de mero mediador entre mercadorias equivalentes segundo o tempo de trabalho nelas contido, o dinheiro torna-se o princípio e o fim de toda a dinâmica social, fazendo da finalidade social a sua própria multiplicação. Mas há elementos nessa reflexão explorados de modo substancial por David Harvey que demonstram já as implicações espaciais dessa função do dinheiro: como mediador no mundo das mercadorias, o dinheiro separa temporal e espacialmente o processo de venda do processo de compra, na medida em que, consoante com sua primeira função, um indivíduo pode portar o dinheiro como medida do valor e, portanto, só lançá-lo de volta ao mercado assim que achar aquilo que lhe agrada no mundo das mercadorias. Ora, isso cria potencialidades novas: ao invés de estocar mercadorias que possam estragar, posso vendê-las imediatamente e guardar apenas o dinheiro como a síntese da riqueza produzida. Mas também complicações absurdamente problemáticas: posso reter dinheiro e outro vendedor não consegue vender suas mercadorias, implicando em prejuízos em sua produção, transformando sua produção em tempo de trabalho inutilmente despendido.

A separação entre o momento de compra e venda, realizado pelo dinheiro, cria as condições para a crise. Mas é preciso ressaltar, contudo, que não é o dinheiro responsável 
pelas crises - embora ele seja seu vetor. A crise é apenas o desdobramento inevitável, através da tensão estendida entre mercadoria e dinheiro, das contradições internas da própria mercadoria (valor de uso e valor, forma e matéria). "Na crise, a antítese entre a mercadoria e sua figura de valor, o dinheiro, é elevada a uma contradição absoluta" (Marx, 1985a: 116). Dinheiro acumulado de um lado e mercadorias paradas de outro são a manifestação empiricamente dramática da contradição entre a forma abstrata e antissocial do valor e a natureza sensível do mundo material. ${ }^{7}$

13 Aqui fica patente outro uso que pode ser dado ao dinheiro enquanto tal, proveniente de sua função como medida de valor: o entesouramento. Se o dinheiro fica retido em uma determinada esfera apenas como medida de valor, esperando um momento propício para seu uso ou mesmo com a irracionalidade da acumulação monetária direta, então o seu caráter de síntese abstrata da riqueza social entre em contradição com sua função de mediador das riquezas concretas. A contradição leva ao paroxismo: acumula-se riqueza em forma monetária sem que se possa desfrutar propriamente dessa riqueza. Marx tem várias passagens ironizando a figura do entesourador, recorrendo a consagradas personagens literárias para dar conta desse abjeto indivíduo que "abraça com seriedade o evangelho da abstenção" (Marx, 1985a: 113).

Sua ironia, entretanto, resvala em uma interpretação histórica que pode ser criticada.

Embora sem dúvida a figura de "vender muito e comprar pouco" (Marx, 1985a: 113) seja comum a diversas sociedades antes da formação da sociedade capitalista, não parece que seja correta sua interpretação de que em sociedades passadas o "dinheiro valia como figura alienada de todas as coisas" (1985a: 112). A não ser que se compreenda o papel das relações religiosas nessa figuração, pois a historiografia recente tem demonstrado o papel sacrificial do dinheiro em sociedades em que o mercado enquanto tal não existia dinheiro desprovido, portanto, de qualquer identidade conceitual com a "medida de valor moderna". ${ }^{8}$ Nessa linha interpretativa, Marx acredita que o entesourador é apenas uma forma inicial e irracional que dá passagem ao capitalista enquanto tal, que acumula dinheiro não pela sua retenção, mas pelo seu constante investimento.

Nessa forma avara fica nítido como o dinheiro, uma mercadoria autonomizada posta ao lado das demais mercadorias, assume um gigantesco poder, medindo "o grau de sua força de atração sobre todos os elementos da riqueza material” (Marx, 1985a: 113). Contudo, isso ainda não é a expressão máxima do poder assumido pelo dinheiro. 0 próprio capitalista é a expressão mais desenvolvida desse poder, na medida em que a força social concentrada não fica parada em suas mãos, mas mobiliza diversas mercadorias (máquinas, matéria-prima, força de trabalho) e com isso produz mercadorias com um valor ainda maior do que o inicialmente investido em forma monetária (mais valor). Essa capacidade de multiplicar o dinheiro através de sua metamorfose em várias mercadorias se deve à força de mobilizar uma mercadoria especial (força de trabalho) capaz de gerar mais valor do que o valor que efetivamente custa. O princípio e o fim da sociedade são ditados pelo dinheiro, mas não sob a forma imediata de transmutar-se em mercadorias equivalentes, e sim com a capacidade de multiplicar-se - a forma dinâmica de acumulação ampliada.

16 Através da cisão entre o momento de venda e momento de compra, fica evidente a capacidade que o dinheiro passa a ter de fragmentar a realidade burguesa. Trocar mercadorias por dinheiro se torna algo distinto de trocar dinheiro por mercadorias. Compra e venda se tornam diferentes. Isso cria também a condição para separar e afastar, temporal e espacialmente, o momento de comprar do momento de pagar! 
Um indivíduo pode adquirir mercadorias sem transferir imediatamente dinheiro para aquele que as vende, seja porque o valor dessas mercadorias é alto, seja porque o consumo delas será demorado e se estenderá por longos períodos, ou mesmo porque será através do consumo dessas mercadorias que o comprador poderá obter o dinheiro necessário para pagá-las. Assim, o vendedor adianta as mercadorias, tornando-se credor; o comprador firma um compromisso de pagamento, torna-se devedor. $O$ dinheiro não paga imediatamente a mercadoria - pode fazê-lo parcialmente através de diversos pequenos pagamentos ou então somente depois de determinado prazo acertado. Com o acordo assumido pelo pagamento, o comprador se compromete a transferir futuramente dinheiro para seu parceiro no negócio, ao vendedor, que tem a garantia de receber futuramente pelas mercadorias que já alienou. $O$ dinheiro, nesse caso, não serve como meio de circulação, pois na verdade as mercadorias já circularam, mudaram de proprietário. O dinheiro converte-se em meio de pagamento. Pagamento de um compromisso firmado, uma dívida assumida, retribuição por um adiantamento de mercadorias.

O mesmo pode ocorrer num sentido inverso: dinheiro pode ser adiantado ao vendedor de mercadorias sem que sua contrapartida seja encaminhada. Um produtor de determinada mercadoria pode precisar de recursos adiantados para colocar seus meios de produção para funcionar (remunerar funcionários, comprar matéria-prima, pagar a conta de luz). Assim, dirige-se a um emprestador que lhe fornece de modo adiantado os recursos monetários que vai precisar. Ao fim de um determinado tempo, o acordo firmado pode ser fechado com a entrega das mercadorias, sua circulação efetiva ou, o que é mais comum, com a devolução dos recursos adiantados acrescidos de uma quantia a mais de dinheiro. Temos aqui a origem dos juros - a forma de remuneração de capital emprestado, isto é, de adiantamento de dinheiro. No caso específico, os juros, o dinheiro pago pelo uso do dinheiro de outrem, não passa da dedução do lucro obtido através da utilização de meios de produção para produzir mercadorias. A opção para o pagamento do recurso adiantado pode ser a entrega das mercadorias assim que produzidas ou a devolução de dinheiro acrescido de juros - de qualquer maneira, as próprias mercadorias produzidas podem ser a garantia de que o emprestador retomará seu dinheiro adiantado.

19 Esse exemplo demonstra muito claramente como o dinheiro, originado do mundo das mercadorias, distancia-se dessas e passa a dominá-las, criando um complexo de formas que ultrapassam a mera função de representação de valor. Essa complexidade é tal que do próprio sistema erigido pelo dinheiro surge um novo sistema - o de crédito. Surge o sistema de adiantamento, empréstimo, remuneração e compensação de créditos e débitos. Isso porque se as mercadorias ainda não produzidas podem se tornar a garantia de um emprestador, então os documentos firmados no empréstimo inicial podem se tornar o certificado da propriedade futura dessas mercadorias, assim como um contrato firmado para pagamento futuro de mercadorias já adiantadas pode se tornar uma letra de câmbio. A partir dessas formas simplórias de moeda de crédito, surgem novas complexidades na relação entre mercadoria e dinheiro, pois um mero documento (certificado ou letra de câmbio) pode circular ao lado das demais mercadorias e ao lado do dinheiro, ${ }^{9}$ servindo esse mero papel como medida de valor, meio de circulação, meio de pagamento ou dinheiro mundial.

Esta última função do dinheiro foi pouca desenvolvida por Marx mas já adiantada em suas várias reflexões sobre a complexidade do sistema monetário: o dinheiro supera as fronteiras nacionais e pode ser utilizado tanto como meio geral de pagamento, como meio 
universal de compra e materialização geral da riqueza - operando aí na compensação de saldos internacionais, compra de produtos diferentes no mercado de outras nações e ainda para a transferência de riqueza sob forma de empréstimos, subsídios, financiamento de guerras etc.

É essa complexidade assumida pelo dinheiro -- de uma mera mercadoria fixada entre outras até a plenitude de representante universal da riqueza -- que define a própria mudança qualitativa em sua forma. De meio de pagamento, o dinheiro se converte em dinheiro de crédito; como dinheiro de crédito, suas funções se ampliam para além do mero adiantamento de mercadorias ou de certificado de dívidas, transformando-se em letras para compensação, título de renda etc.

o dinheiro de crédito se origina diretamente da função do dinheiro como meio de pagamento, já que são colocados em circulação os próprios certificados de dívidas por mercadorias vendidas, para transferir os respectivos créditos. Por outro lado, ao estender-se o sistema de crédito, estende-se a função do dinheiro como meio de pagamento. Enquanto tal, recebe forma própria da existência, na qual ocupa a esfera das grandes transações comerciais, enquanto as moedas de ouro e prata ficam confinadas à esfera do varejo.

Com certo nível e volume de produção de mercadorias, a função do dinheiro como meio de pagamento ultrapassa a esfera da circulação de mercadorias. Ele torna-se a mercadoria geral dos contratos (Marx, 1985a: 117).

Ao especificar a diferença entre medida de valor e padrão dos preços, supomos o dinheiro na forma da moeda metálica, isto é, até o momento tratamos o equivalente geral como a mercadoria ouro ou prata. No desenvolvimento histórico do mercado, esses materiais foram os mais adequados ao papel formal que deveriam cumprir - são mercadorias de fácil utilização, de grande valor (uma pequena fração de cada um exige um longo tempo de trabalho), de fácil divisão e fracionamento, assim como grande durabilidade. Suas formas físicas correspondiam, assim, às exigências funcionais da forma dinheiro. Ao chegar ao ápice das funções do dinheiro, Marx também opera o conceito de dinheiro mundial através das moedas metálicas, pois elas podiam ser diretamente aceitas em transações internacionais, bastando as nações derretê-las e colocar o selo com o nome que lhes convir. ${ }^{10}$

O salto do sistema monetário para o sistema de crédito é, em linhas gerais, a superação da forma material da moeda por uma forma puramente fiduciária - a moeda de crédito. Contudo, mesmo na forma de moeda de crédito, ou seja, notas promissórias, letras de câmbio, certificado de dívidas etc., o dinheiro representa uma determinada quantidade de mercadoria que lhe sustenta enquanto medida de valor, sejam elas mercadorias adiantadas ou prometidas, seja a mercadoria-dinheiro (ouro, prata) emprestada ou a ser reembolsada.

Evidente que, como promessa de pagamento, recebimento, adiantamento ou compromisso de fornecimento de mercadorias, as moedas de crédito podem, de uma hora para outra, virar mero papel sem valor algum, pois o compromisso estabelecido previamente pode ser rompido ou nunca vir a ser cumprido. Isso cria dificuldades que não apenas repercutem as contradições já existentes entre valor de uso e valor, mercadoria e dinheiro, como adicionam complexidades novas como essa tensão entre dinheiro e dinheiro de crédito. Como um "sistema nervoso central" (EI: 270; EM: 274; EB: 358), o sistema de crédito sintetiza e amplifica todas as contradições do capitalismo.

Uma das formas de amenizar essas tensões é a criação das instituições bancárias, cuja função precípua é converter moeda de crédito aceita apenas por um grupo seleto de 
indivíduos -- que confiam no vendedor ou comprador particular envolvido na negociação ainda não totalmente encerrada (adiantamento de mercadoria ou pagamento antecipado) - por moeda de crédito com um grau de confiança muito mais largo. Essa confiança surge porque a instituição bancária deve conter, a princípio, os recursos necessários para saldar os compromissos assumidos por outros, ou porque sua abrangência é muito maior, portanto seus documentos podem ser aceitos por indivíduos sem necessidade de nenhuma confiança pessoal nos envolvidos em determinada negociação.

Quando os bancos emitem seus próprios certificados (notes) ou permitem cheques baseados nestes, eles substituem com a sua própria garantia a de inumeráveis capitalistas individuais. Quando o sistema de troca é relativamente simples, o conhecimento pessoal e a confiança dos capitalistas individuais pode garantir a qualidade das dívidas contraídas, mas em um sistema complexo de mercado isto não pode formar um fundamento adequado para o sistema de crédito. $O$ banco trata de institucionalizar o que anteriormente era um assunto de confiança e credibilidade pessoal entre os capitalistas individuais. A maioria das letras de câmbio que se originam de capitalistas individuais será livremente convertida em dinheiro bancário. Mas se o banco tem de manter a qualidade de sua própria moeda, deve conservar o direito de recusar aquelas letras que considere arriscadas ou sem valor. O banco monitora a credibilidade dos capitalistas individuais e atua como intermediário destes (EI: 247; EM: 252; EB: 330). ${ }^{11}$

Ora, mas esse método de amenizar as possibilidades de uma moeda de crédito não ter lastro material (em mercadorias) ou monetário (dinheiro) oferecido pelo sistema bancário cria novas complexidades. Ao reunir uma série de moedas, títulos, certificados e promessas de pagamentos, o banco concentra uma grande quantidade de moeda que se desvinculou de sua "base material", ou seja, seus fundamentos na mercadoria (seja a mercadoria enquanto tal ou a mercadoria-dinheiro). Para evitar uma ampliação desmesurada desses papéis, o banco precisa ter uma certa quantidade de moeda sonante em seus cofres, para garantir as conversões da moeda creditícia em mercadoria-dinheiro. Contudo, não é possível para o banco estabelecer uma relação direta entre o volume de crédito fornecido e os depósitos correntes, pois a moeda de crédito, em sua própria forma, é a síntese monetária de uma futura produção ou compensação. Portanto, não é possível, pela própria natureza do crédito, que toda sua face nominal seja diretamente expressão de moeda efetiva. Isso seria um contrassenso que tornaria o próprio dinheiro de crédito dispensável. Assim como ocorre com o depósito comum nos bancos comerciais, em que a soma total dos depósitos nunca está imediatamente disponível para ser sacada, o mesmo ocorre em relação à correspondência das moedas de crédito fornecidas pelos bancos e o dinheiro disponível para quitá-las.

Cada banco deve manter uma reserva de ouro para este propósito. Sob condições normais, a reserva de ouro somente precisa ser uma pequena proporção de valor total das mercadorias em circulação, o suficiente para balancear as contas entre os bancos. Entretanto, quando está sob dúvida o valor das mercadorias no mercado, a necessidade de uma reserva adequada de mercadoria-dinheiro se torna urgente do contrário, o banco pode falir. Por outro lado, transportar ouro e armazená-lo é complicado, arriscado e ineficiente. Outro caminho tem de ser encontrado para fazer com que as diversas moedas bancárias possam ser livremente convertidas umas nas outras (EI: 247; EM: 252; EB: 331).

O problema é ainda mais grave porque os bancos são instituições capitalistas como qualquer outra - com a diferença de que a mercadoria que negociam é exatamente essa mercadoria especial, dinheiro. Isto é, o capital bancário é aquele que negocia o dinheiro como uma mercadoria, enquanto o resto da sociedade precisa da mercadoria enquanto 
dinheiro para fazer suas compras, contratos, consumo etc. Isso exige uma atuação dinâmica do banco no mercado, pois ele precisa competir com outras instituições concorrentes que negociam a mesma mercadoria. As implicações da concorrência inerente ao sistema bancário acabam por ampliar as tensões presentes nessa relação inicialmente já problemática entre mercadoria e dinheiro, só que agora na forma da contradição entre dinheiro enquanto mercadoria (dinheiro como meio) e dinheiro enquanto dinheiro (dinheiro como fim). Através da oferta de meios de financiamento e de taxas de juros mais ou menos competitivas, os bancos podem ampliar a desproporção entre o lastro material e as moedas de créditos, ofertando mais volume de crédito para compensar as reduções nas taxas de juros frente à concorrência. Através das diversas formas de financiamento da produção, do consumo e mesmo de financiamento da administração pública, amplia-se o fosso entre crédito e depósitos. Diante de dificuldades, um banco pode solicitar recursos de um concorrente para saldar seus próprios compromissos, mas mesmo que isso implique na alienação dos seus rendimentos (juros) para quem lhe socorre, o intervalo entre os depósitos materiais e o crédito gerado continua sendo significativo. Essa solução de um banco socorrer a outro é temporária, pois recursos são apenas transferidos (no caso de o empréstimo ocorrer em moeda metálica) ou então o volume de crédito é ampliado ainda mais na operação (no caso de o empréstimo ocorrer por meio da emissão de crédito de um banco para outro). Isso cria tensões crescentes, pois as divergências entre crédito e dinheiro apenas se ampliam, tornando essas dificuldades epidêmicas. Para isso surge o banco central.

No início, as funções de um banco central foram realizadas por alguma instituição bancária privada ou por um conjunto delas (EI: 248; EM: 252-253; EB: 331), mas ainda assim eram obrigações limitadas frente àquelas que assumiram no século $\mathrm{XX}$ os bancos centrais estatais. Mas desde o início uma de suas primeiras exigências fundamentais, sem dúvida, foi a garantia da qualidade do dinheiro corrente. No caso em que o dinheiro ainda era a moeda metálica, comprovar sua pureza na quantidade estipulada de ouro ou prata; no caso das moedas de crédito em circulação, assegurar que os bancos que as emitem possam ter algum tipo de depósito absoluto final para recorrer caso sua confiabilidade esteja em xeque. Assim, a função de um banco central é ampliar e aprofundar ainda mais o grau de confiança das diversas formas de dinheiro em circulação, principalmente assegurar que, dada a distância inevitável estabelecida entre moeda de crédito e seus fundamentos materiais, esse intervalo possa ser administrado regularmente através das compensações da riqueza geral existente na sociedade e parcialmente depositada nos bancos particulares.

Um banco central de algum tipo pode resolver este problema. Ele fornece os meios para os bancos equilibrarem suas contas entre si sem ter que remeter ouro de um lado a outro. Para fazer isso, o banco central deve possuir dinheiro de alta qualidade que pode garantir a segurança das transações entre os bancos. 0 dinheiro dos bancos individuais é livremente conversível em moeda do banco central somente quando o banco central está satisfeito com a qualidade ou a solidez do dinheiro do banco individual. 0 banco central forma o próximo nível na hierarquia das instituições monetárias. A partir desse posto de comando, o banco central procura garantir a solvência e a qualidade da moeda dos bancos privados. (EI: 247; EM: 252; EB: 331).

O problema é que, como se pode imaginar a partir dessa reflexão, o banco central é apenas um entre outros bancos, embora seja uma "instituição de ordem superior" (EI: 248; EM: 254; EB: 333). Apesar de ter passado a desempenhar algumas funções exclusivas definição da taxa dos juros dos títulos de dívida emitidos pelos governos, lastro e emissão 
das moedas nacionais etc. - seu mecanismo de funcionamento é o mesmo que os demais, consistindo basicamente em operar com a capacidade do dinheiro em funcionar como meio de pagamento e medida de valor. ${ }^{12} \mathrm{Um}$ dos principais modos do banco central realizar essa garantia em última instância do sistema de crédito é através da obrigação de que os bancos particulares entreguem uma fração de seus depósitos em moeda. Ou seja, a transferência compulsória de parte dos depósitos em dinheiro para o banco central lhe permite operar com recursos para saldar possíveis lapsos criados entre a oferta de crédito realizada por uma instituição particular e suas obrigações. No fundo, trata-se de garantir que o dinheiro de crédito que brota do processo mesmo de circulação das mercadorias e do dinheiro seja o espelho, em algum momento, de uma riqueza real existente, ou seja, uma mercadoria que tem a função de servir como dinheiro. $O$ que temos aqui é a contradição estabelecida entre, de um lado, a economia capitalista ser uma economia real em que riqueza é mobilizada sob a forma de mercadoria e uma economia monetária em que a riqueza é espelhada não apenas no dinheiro enquanto tal (a moeda metálica que é uma mercadoria) mas em diversas formas de dinheiro de crédito. ${ }^{13}$

Embora tenhamos grosseiramente simplificado a estrutura e, certamente, abstraído as complexidades das circunstâncias históricas, o caráter hierárquico de instituições monetárias pode ser claramente estabelecido como o corolário necessário para a existência de moedas de crédito. A necessidade para tal ordem hierárquica pode ser rastreada até a subjacente contradição entre o dinheiro como medida de valor e dinheiro como um meio de circulação. Embora a moeda de crédito apareça soberbamente adaptada para funcionar como meio quase sem atrito de circulação, sua capacidade de representar os valores "reais" das mercadorias está perpetuamente sob suspeita. A noção de alguma medida absoluta de valor pode parecer redundante em qualquer nível particular da hierarquia, mas o problema da qualidade do dinheiro permanece - e o que é essa qualidade se não uma garantia de que a quantia nominal da moeda de crédito, de fato, representa os valores reais das mercadorias? (EI: 249; EM: 254; EB: 333).

Nem sempre, contudo, o próprio banco central consegue realizar o controle e regular a oferta de crédito produzida pelas instituições particulares com o depósito existente de dinheiro. No caso de explosão de uma crise nos mercados de crédito, contágio que leva à cobrança generalizada ou à venda indiscriminada de moeda de crédito e absoluta falta de confiança, é perfeitamente normal - e catastrófico - que o volume de crédito produzido pelas diversas formas de moeda, compromissos, letras e certificados emitidos pelos bancos seja incompatível com o dinheiro disponível em ouro ou prata. Ocorre aqui o "salto brusco do sistema de crédito para o sistema monetário [que] acrescenta o susto teórico ao pânico prático: e os agentes da circulação estremecem perante o mistério impenetrável" (Marx, 1985a: 116). É absolutamente necessária a desvalorização dos preços constantes nas moedas emitidas indiscriminadamente, forçando assim um ajuste entre a massa monetária creditícia e a massa de moeda metálica. Como guardião da moeda metálica, o banco central pode agir seletivamente optando por aquelas instituições que são as mais "responsáveis" e foram afetadas pela avalanche provocada por aquelas mais frágeis e "irresponsáveis", que emitiram crédito pouco confiável. ${ }^{14}$ Entretanto, mesmo que as responsabilidades sejam apuradas e opções sejam feitas na hora de mobilizar os recursos de emergência, quase sempre uma parte do dinheiro público arrecadado dos impostos acaba sendo desviada para que o sistema de crédito não desmonte sobre suas próprias bases. Recai sobre o banco central o peso de se comprometer com instituições financeiras sob a justificativa de que o estrago seria ainda maior caso implodissem. No fundo, o banco central é um banco como qualquer outro, mas ao invés de recorrer aos 
depósitos de outra instituição para cobrir o buraco aberto entre crédito e dinheiro, ele recorre à sociedade como um todo.

Como dito acima, toda essa discussão ainda é feita nos marcos de uma situação histórica em que o dinheiro é imediatamente metal, portanto, o dinheiro é uma mercadoria dotada de valor, funcionando como medida de valor devido ao fato de ser a síntese de um tempo de trabalho socialmente necessário para a sua produção. Assim, a tensão entre moeda de crédito e dinheiro, ou moeda metálica, é evidente: de um lado temos apenas uma representação da riqueza mercantil, moeda aceita nas transações diárias apenas na medida em que será futuramente convertida em mercadoria ou em dinheiro; de outro temos a mercadoria propriamente dita, fundamento daquele crédito gerado. Isso significa que, em determinadas condições históricas - mais precisamente: até um determinado nível de desenvolvimento capitalista, os depósitos que formam a base que sustenta a economia de crédito desenvolvida com o desprendimento das moedas creditícias é a moeda metálica. São as moedas de ouro que ainda seguram a linha que impede o crédito de flutuar folgadamente. Como equivalente universal da riqueza e medida de valor, o ouro pode servir como o anteparo final de toda essa emissão desenfreada de moedas que se encaixam no intervalo entre a entrega de mercadorias e o pagamento ou o empréstimo de dinheiro e sua restituição. Como meio de pagamento e dinheiro mundial, o ouro é o fundamento último da economia desdobrada sobre a contradição entre valor e valor de uso, mercadoria e dinheiro.

o problema é que o ouro só foi utilizado como moeda corrente durante determinada etapa da história capitalista. Uma série de exigências e limitações históricas fizeram com que o ouro aos poucos fosse simplesmente deixado depositado nos bancos - e os bancos centrais começaram a concentrar os estoques de ouro devido às funções de garantidores últimos da qualidade da moeda. Ao invés da circulação direta de ouro, papel-moeda passou a circular representando uma determinada quantidade desse metal. $O$ papelmoeda, assim, representava uma determinada quantidade de riqueza real fora de seu corpo material - enquanto o ouro ainda era, ao mesmo tempo, a riqueza monetária e material básica.

Como toda moeda que representa a perspectiva futura de pagamento ou de entrega material de mercadorias, o papel-moeda nada mais é do que uma convenção baseada na confiança de sua possibilidade de resgate, a conversão em ouro. Com o tempo, contudo, assim como ocorreu com o ouro que devido a determinadas circunstâncias deixou de ser nominalmente idêntico à sua quantidade real, um banco central pode emitir papel-moeda para além da correspondência direta com os depósitos em ouro em seu poder. A massa monetária disponibilizada pode ser maior -- para incentivar o crédito, ampliar o poder de consumo ou afetar de alguma maneira o processo econômico - do que a sua base real em ouro. Isso significa que o próprio dinheiro deixa de ser totalmente conversível em ouro: assim como ocorre no dia-a-dia de uma instituição bancária comum que emite moedas de crédito para garantir uma negociação ainda por realizar, o forno central do sistema monetário, o banco central, pode emitir papel-moeda de acordo com as necessidades ditadas em determinado momento. Em ocasião de grandes turbulências financeiras, com o próprio colapso do mercado em curso, com a quebra progressiva das instituições bancárias, um banco central pode inclusive desincumbir-se da obrigação de fornecer depósitos metálicos para os bancos em dificuldades e simplesmente lançar papel-moeda para apagar o incêndio financeiro. Ou seja, frente ao risco de esgotamento das bases reais da riqueza monetária devido aos rombos acentuados no mercado de crédito, um banco 
central pode romper a conversibilidade total da moeda e lançar indiscriminadamente papel-moeda simplesmente como uma moeda de crédito qualquer no mercado. A diferença consiste, nesse caso, que diferente de um dinheiro de crédito comum emitido por um banco qualquer, o papel-moeda emitido pelo Estado é amplamente aceito em suas fronteiras. Mas, mesmo isso, isso pode não conseguir seu intento, já que o risco dessa emissão desenfreada é exatamente a perda de poder de compra do papel-moeda, sua desvalorização e a pouca confiança que produz.

$\mathrm{Na}$ verdade, isso não apenas se tornou uma estratégia recorrente em momentos de dificuldade, como desde 1971 a economia mundial como um todo já não tem mais as bases reais de um dinheiro que seja ao mesmo tempo mercadoria. Antes realizada isolada e temporariamente em momentos de dificuldade financeira ou conflagração - por exemplo, entre as duas guerras mundiais --, a desvinculação das moedas correntes do ouro se tornou uma realidade cotidiana assim que os EUA romperam unilateralmente com esse lastro. Dado que desde os acordos de Bretton Woods o dólar era a moeda hegemônica e o fundamento das demais moedas nacionais, o fim do lastro metálico do dólar significou o fim do lastro de todas as moedas e desde então a determinação da qualidade dessas moedas se tornou um problema mundial. o fim do dinheiro-mercadoria como referência significou o rompimento da representação da riqueza de sua base propriamente dita e uma instabilidade permanente no sistema monetário mundial.

Quando a maior parte das reservas mundiais de ouro estavam trancados no Fort Knox e os Estados Unidos tinham uma posição dominante em termos de balança de pagamentos e comércio mundial, o padrão dólar fixado no Bretton Woods Agreement de 1944 pode prevalecer e o dólar tornou-se, com efeito, o equivalente universal. Mas a deterioração da balança de pagamentos e a concorrência cada vez mais feroz da Alemanha Ocidental e Japão fizeram para os Estados Unidos, internacionalmente, o que a concorrência dos bancos do centro-oeste e do extremooeste fez para JP Morgan. A subsequente desvalorização do dólar em 1971 assinalou o colapso do Bretton Woods Agreement e a busca de uma nova ordem monetária internacional começou. Uma série de expedientes paliativos foram criados e tentativas de estabelecer algum tipo de papel-moeda de qualidade superior supranacional - como os direitos especiais de saque do Fundo Monetário Internacional ("papel-ouro") -- foram feitas. Mas, como De Brunhoff aponta, essas tentativas foram fundadas sobre a proposição falaciosa de que uma forma de moeda de crédito poderia funcionar como a medida final do valor. Desde então nenhuma maneira foi encontrada para garantir a qualidade das moedas nacionais, exceto amarrá-las à produção de alguma mercadoria específica (EI: 249; EM: 253; EB: 332-333).

Aqui, uma série de questões poderiam ser desenvolvidas, como, por exemplo, o fato de que através da emissão de papel-moeda sem conversão proporcional ou mesmo sem conversão alguma o Estado pode ampliar a oferta disponível de crédito conforme seus interesses. Isso significa que o Estado é a instituição que mais facilmente pode simular a riqueza em forma monetária, pode criar riqueza monetária sem base real. o Estado é um dos principais responsáveis pela ficcionalização do capital. As instituições financeiras, através das moedas de crédito podem também ampliar, inflar e reduzir a riqueza monetária simulando dinheiro através dos sucedâneos das moedas de crédito que são aceitas regularmente no mercado. $\mathrm{Na}$ verdade, a própria moeda de crédito enquanto tal, através da função do dinheiro como meio de pagamento, é o fundamento e a origem do capital fictício. A partir da possibilidade contida nos certificados, letras de câmbio, títulos e compromissos de pagamento, uma riqueza futura pode ser experimentada já no presente como se existisse de fato, quando na verdade o que existe é apenas a sua promessa futura. 
A potencialidade para o "capital fictício" encontra-se no interior da própria forma dinheiro e está particularmente associada ao surgimento da moeda de crédito. Considere o caso de um produtor que recebe crédito em troca da garantia de uma mercadoria não vendida. $O$ dinheiro equivalente à mercadoria é adquirido antes de uma venda real. Esse dinheiro pode então ser utilizado para comprar novos meios de produção e força de trabalho. 0 credor, no entanto, tem um pedaço de papel cujo valor é apoiado por uma mercadoria não vendida. Esta peça de papel pode ser caracterizada como valor fictício. O crédito comercial de qualquer tipo cria esses valores fictícios. Se os pedaços de papel (principalmente letras de câmbio) começam a circular como moeda de crédito, então é valor fictício que está circulando. Assim, abre-se a diferença entre moedas de crédito (que sempre têm um componente fictício, imaginário) e dinheiros 'reais' diretamente vinculados a uma mercadoria monetária. Se esse dinheiro de crédito é emprestado como capital, ele então tornase capital fictício (EI: 267; EM: 271; EB: 353-354). ${ }^{15}$ dinheiro e do crédito tal como exposta em 0 Capital de Marx e apresentada por Harvey em Os Limites do Capital. Evitamos fazer comentários críticos sobre essa apresentação porque, em primeiro lugar, é uma das melhores interpretações disponíveis na "marxologia" para essas questões. A exposição de Harvey está acima da média do que é o costume no marxismo. Segundo, porque evitamos assim perturbar o desdobramento categorial com alguma discussão lógica ou metodológica. Evidentemente, Harvey não expõe o processo de desenvolvimento que vai da mercadoria ao dinheiro e do dinheiro ao crédito de modo direto e sem comentários históricos ou interpretativos, mas evitamos até o momento considerações externas ao objeto para não interferir na lógica contraditória inerente à teoria do dinheiro.

Dito isso, uma das primeiras observações a ser feita sobre o tratamento teórico que Harvey imprime ao dinheiro e ao crédito na obra de Marx é uma certa leitura histórica 
ortodoxa questionável que enxerga a economia monetária como uma característica não exclusiva do capitalismo. Segundo Harvey,

Marx constrói sua teoria do dinheiro a partir de uma investigação da produção e da troca de mercadorias, sem qualquer referência à circulação do capital. Ele toma esse caminho porque uma economia monetária é comum a vários modos de produção diferentes e não específica do capitalismo (EI: 251; EM: 256; EB: 335).

Há aqui duas confusões que nos parecem importantes. A primeira é o fato de que a derivação lógica do dinheiro partir da mercadoria e do valor, abstraindo qualquer referência à circulação do capital, não implica numa ignorância completa da circulação enquanto tal. Ou seja, é evidente que a intenção marxiana é expor as contradições internas da mercadoria que desembocam necessariamente no dinheiro - portanto, na contradição externa entre dinheiro e mercadoria. Que isso seja feito, a principio, com uma indiferença frente à circulação de capital é imediatamente remediado, pois o segundo capítulo de 0 Capital, "O processo de troca", já nos traz a interversão entre circulação simples e circulação capitalista como pressuposto necessário da própria forma generalizada da troca de mercadorias por dinheiro, ou seja, de uma economia monetária. A observação que fizemos sobre o trabalho socialmente necessário pode ser repetida aqui: embora o dinheiro seja derivado da forma simples da mercadoria não significa que o conjunto das mercadorias, a forma social, não esteja pressuposta nessa análise.

41 A outra observação, mais importante ainda, mas também de ordem lógica, é a interpretação ortodoxa de que a circulação simples de mercadorias, plano lógico por meio do qual Marx desenvolve toda a primeira seção de $O$ Capital, seria um estágio histórico anterior à própria produção capitalista e base por meio do qual ela seria desenvolvida. ${ }^{16} \mathrm{O}$ equívoco aqui é gigantesco e não é exclusivo de Harvey e envolve essa categoria "circulação simples" que tem, em Marx, uma função de difícil determinação, pois embora seja um recurso lógico (heurístico) para apresentar as conexões internas das formas de sociabilidade burguesa, é também uma evidência real na medida em que a concepção de uma circulação de mercadorias onde todos interagem como proprietários autônomos e com poderes idênticos, trocando objetos com valores equivalentes, é a aparência socialmente necessária dessa sociedade. ${ }^{17}$

Ora, não existe nenhuma economia monetária a não ser a economia capitalista, pois somente nessa formação social todos os objetos se transformaram em mercadoria e, assim, podem ser trocados, podem circular num processo global e ininterrupto. A própria ideia de circulação é estranha a qualquer realidade pré ou não-capitalista, pois até os primórdios da modernidade as relações mercantis estiveram presentes apenas parcialmente e embebidas em relações culturais e religiosas cujo sentido e objetivo era diverso da moderna troca de mercadorias. Mesmo no livro II de O Capital, que Harvey cita em nota para comprovar essa afirmação sobre a anterioridade das relações monetárias, é possível verificar a visão marxiana de que economia monetária inexiste até o desenrolar capitalista. Ao tratar exatamente da reprodução simples, Marx mostra como, embora o uso de dinheiro preceda a produção capitalista, apenas sob estas condições ocorre efetivamente uma circulação total das mercadorias e do dinheiro:

Na medida em que se desenvolve o sistema de trabalho assalariado, todo produto se transforma em mercadoria e, por conseguinte, tem de percorrer em sua totalidade com algumas exceções importantes - a transformação em dinheiro como uma fase de seu movimento. A massa do dinheiro circulante tem de ser suficiente para converter em prata as mercadorias, e a maior parte dessa massa é fornecida em forma de salários, de dinheiro que, adiantado pelos capitalistas industriais como 
forma-dinheiro do capital variável no pagamento da força de trabalho, funciona em sua maior parte - nas mãos dos trabalhadores como meio de circulação (meio de compra). Isto está em oposição total à economia natural, tal como predomina sobre a base de todo sistema de dependência (inclusive servidão) e mais ainda sobre as comunidades mais ou menos primitivas, existam ou não nestas relações de dependência ou de escravatura (Marx, 1985b: 348-349).

Continua Marx a demonstrar que mesmo entre os atenienses (presumido povo comercial) e os romanos da Antiguidade, a forma básica da produção, o escravismo, tinha sua fonte não em um mercado de força de trabalho, mas na economia natural da pilhagem e subordinação. ${ }^{18}$

A ideia de uma economia monetária que preceda o capitalismo é, portanto, uma interpretação enviesada da lógica de 0 Capital e, principalmente, uma leitura histórica equivocada. E isso não é apenas um pequeno deslize histórico, pois a implicação disso é a aceitação de uma necessidade de manutenção de alguma forma de economia monetária para além do capitalismo. Uma posição crítica seria enxergar que o dinheiro enquanto tal não é produto histórico anterior ao capitalismo, mas é o resultado da lógica da mercadoria levada ao extremo da autonomização - sendo o capital fictício sua forma mais desenvolvida, como mostra o próprio Harvey. Dito isso, nenhuma transição póscapitalista poderia fazer uso dessa forma ingenuamente, tomando-a como neutra, pois isso seria incorrer numa reprodução inconsciente das bases sociais que tornam possível a própria sociedade capitalista - o fracasso do socialismo real teria muito a nos ensinar nesse sentido.

As repercussões mais avançadas - e problemáticas - dessa interpretação talvez apareçam em recentes posicionamentos de Harvey frente à crise financeira, quando salienta a necessidade dos grupos de esquerda de fazer algum tipo de luta dentro do sistema financeiro, para torná-lo mais democrático e socializado.

(...) o capitalismo está mudando, e suas formas de organização mudam algumas possibilidades. Uma das coisas que a esquerda precisa começar a pensar é como ela pode fazer essa luta de classes contra o sistema financeiro. Você pode fazer uma luta contra os bônus bancários, mas será que você pode lutar contra o sistema financeiro e transformá-lo, para que ele se torne mais socializado e mais democrático? É uma questão enorme, porque, se este for um instrumento de poder pra classe capitalista, é aí que você tem que ir, pra tentar confrontar o poder do capital. Essas transformações ocorreram em todos os tipos de área (Harvey, 2012: 23).

Como dito, essa linha de avaliação do papel do dinheiro e do crédito no capitalismo não é exclusiva de Harvey, sendo comum à ortodoxia marxista. É possível até mesmo identificar algumas das influências diretas nessa sua visão. Ao longo de Os Limites do Capital, principalmente nos capítulos em que trata do dinheiro e do crédito (capítulos 9 e 10), Harvey utiliza abundantemente a obra da teórica marxista estruturalista Suzanne de Brunhoff. Logo no início do capítulo 9 ("Dinheiro, crédito e finanças"), Harvey destaca a importância dessa autora francesa em sua análise do dinheiro em Marx, indicando ainda a importância de Roman Rosdolsky. ${ }^{19}$

47 No Brasil, Suzanne de Brunhoff é conhecida mais pela publicação de algumas obras sobre o sistema de crédito, particularmente um livro de grande repercussão intitulada A moeda em Marx, publicada na década de $1970 .{ }^{20}$ Embora com algumas importantes questões levantadas em torno da relação entre sistema monetário e sistema de crédito, Brunhoff comete alguns deslizes históricos e teóricos graves. O primeiro deles, e fonte das 
dificuldades presentes na obra de Harvey, é ver o capitalismo como um caso particular das leis gerais da circulação monetária. Existe aqui, portanto, uma concepção do capitalismo como espécie do gênero economia monetária: "Marx relaciona o crédito com o modo de produção capitalista e o distingue da noção geral de moeda, válida para toda a produção mercantil" (Brunhoff, 1978: 17-18). Estamos às voltas com a visão de uma circulação simples como estágio anterior à economia capitalista propriamente dita - esta corresponderia a uma condição nova, devido à transformação do dinheiro em capital, criando novas atribuições e problemas às "leis gerais da circulação monetária" (1978: 15).

O problema metodológico principal no texto de Brunhoff é tomar a teoria de Marx como uma teoria geral da sociedade, seguindo à risca a visão de Althusser. ${ }^{21} \mathrm{~A}$ partir dessa teoria geral e da forma geral de socialização encarada por Marx, seria possível compreender as particularidades da sociedade capitalista. o que Brunhoff faz, assim, é transtornar a teoria crítica do capitalismo desenvolvida por Marx e transformá-la numa interpretação positivada da história da humanidade, universalizando, com isso, formas sociais que são exclusivas à sociedade moderna. Brunhoff faz um estruturalismo grosseiro que naturaliza as relações de troca, transforma a teoria da moeda, no primeiro livro de $O$ Capital, na "versão primitiva do sistema monetário" (1978: 81) e acaba por fixar quase antropologicamente o trabalho abstrato como modelo geral de sociabilidade, medido pela moeda.

Ao comentar a crítica de Rosa Luxemburgo a Marx, Brunhoff argumenta que há em sua abordagem um erro em querer transformar a produção de ouro numa seção particular da economia e, deste modo, numa espécie de mercadoria como as outras (meios de produção, bens de consumo). Isso retiraria da moeda o seu caráter opositivo às demais mercadorias, ainda que nessa visão estivesse correta a idéia de um

meio de circulação independente do capitalismo e muito mais antigo que este. A moeda seria assim incorporada nos esquemas de reprodução capitalista, de uma maneira mais adequada ao seu próprio conceito, como encarnação específica do 'trabalho social in abstracto' em qualquer produção mercantil (Brunhoff, 1978: 66).

O que temos aqui, obviamente, é o tratamento da teoria do dinheiro dos primeiros capítulos de 0 Capital como algo externo ao próprio capital - e não a partir de uma anterioridade lógica fundante. Isso significa que também o trabalho abstrato se torna algo universal. Nisso se perde a compreensão do caráter verdadeiramente original e socialmente destrutivo da produção em condições capitalistas, o fato de as relações sociais se converterem na atividade abstrata de puro dispêndio de tempo de trabalho. A abstração que caracteriza o trabalho abstrato não é enxergada como uma "abstração real", realizada cotidianamente por trás das costas dos indivíduos, mas apenas como uma abstração mental, idealizada, que confere a possibilidade de igualdade dos produtos dessa atividade no mercado. ${ }^{22}$ David Harvey não está isento dessa visão simplificada da abstração promovida pelo trabalho, portanto, os desdobramentos mais avançados de sua teoria podem levar a caminhos tortuosos. ${ }^{23}$

51 No fundo, o que temos aqui é uma teoria que interpreta o capitalismo como uma forma entre outras de economia monetária que se serviu do dinheiro como esse instrumento facilitador e poderoso de se apropriar da riqueza alheia. o problema, assim, não é a forma do equivalente geral enquanto tal, a forma mercadoria ou mesmo a forma abstrata do trabalho, mas o fato de que o trabalho individual acaba sendo indevidamente representado e apropriado por outrem através do dinheiro que circula sob a forma de capital. 
David Harvey já deixava claro, em sua obra principal, o papel especial e poderoso que o dinheiro possui na sociedade burguesa. ${ }^{24} \mathrm{Em}$ artigos mais recentes, contudo, essa sua interpretação que desaprova o dinheiro pelas suas diversas funções, para além de meio de circulação, acabam por ter resultados reformistas evidentes.

Temos de encontrar uma economia política alternativa ao modo como funciona o capitalismo. E temos alguns princípios. Por isso as contradições são interessantes. Examina-se cada uma delas, por exemplo, a contradição entre valor de uso e valor de troca e se diz - "o mundo alternativo é mundo no qual se fornecem valores de uso". Assim podemos nos concentrar nos valores de uso e tentar reduzir o papel dos valores de troca.

Ou, na questão monetária - claro que precisamos de dinheiro para que as mercadorias circulem. Mas o problema do dinheiro é que pessoas privadas podem apropriar-se dele. $\mathrm{O}$ dinheiro torna-se uma modalidade de poder pessoal e, em seguida, um desejo-fetiche. As pessoas mobilizam a vida na procura por esse dinheiro, até quem não sabe que o faz. Então, temos de mudar o sistema monetário - ou se taxam todas as mais-valias que as pessoas comecem a obter ou criamos um sistema monetário no qual a moeda se dissolve e não pode ser entesourada, como o sistema de milhagem aérea (Harvey, 2013).

No fundo, a moeda corresponde à melhor maneira de distribuição da riqueza, o melhor modo de fazer a riqueza circular e dar acesso a todos que contribuem para a produção, ao fruto de seu trabalho - o único problema é seu monopólio privado. A incompreensão de que a circulação simples e a igualdade geral aparente do capitalismo são invertidas cotidianamente pelas suas próprias categorias leva à aceitação dos ideologemas que brotam dessa esfera superficial e fenomênica. Pensar numa "economia política alternativa" ao capitalismo é o resultado de uma apreensão histórica geral da teoria do dinheiro e da moeda, independente da crítica radical do capitalismo.

Ora, por meio dessa "economia política alternativa", a única maneira de pensar em mudança social através da mercadoria e do dinheiro é continuar tentando de alguma maneira evitar que essas formas cheguem às suas últimas consequências lógicas - e que são inevitáveis. Como disse várias vezes Marx, é típico do reformismo pequeno-burguês querer a mercadoria mas não o dinheiro, querer o trabalho mas não o capital, sem entender como necessariamente uma forma está contida na outra. ${ }^{25} \mathrm{Ou}$ seja,

como é impossível suprimir as complicações e contradições derivadas da existência do dinheiro ao lado das mercadorias particulares por meio da modificação da forma do dinheiro (muito embora as dificuldades pertencentes a uma forma inferior possam ser evitadas por uma forma superior), é igualmente impossível suprimir o próprio dinheiro enquanto o valor de troca permanecer a forma social dos produtos. É preciso compreender isso claramente para não se colocar tarefas impossíveis e para conhecer os limites no interior dos quais as reformas monetárias e as transformações da circulação podem fornecer uma nova configuração para as relações de produção e as relações sociais sobre elas fundadas (2011: 95).

E o que parece mais pequeno-burguês do que uma proposta de transformar o sistema monetário num sistema parecido com o de "milhagens aéreas"? Em sua última obra, David Harvey reconhece exatamente essas inquietações, mas na falta de algum propósito mais radical, insiste em algum tipo de circulação monetária capaz de impedir a apropriação privada e acúmulo da riqueza social. Como havíamos constatado antes sobre outro tema em sua obra recente, ${ }^{26}$ Harvey precisa se apoiar em medidas keynesianas para tornar palpáveis essas ideias. $\mathrm{Na}$ verdade, ele resgata mais precisamente a leitura keynesiana da proposta de cédulas de circulação de Silvio Gesell. 
Keynes, em seu influente Teoria Geral do Emprego, do Juro e da Moeda (1936), por exemplo, citava o "estranho e indevidamente esquecido profeta Silvio Gesell", que há muito tempo propôs a criação de uma espécie de paradinheiro que se oxidaria se não fosse utilizado. A desigualdade fundamental entre mercadorias (valores de uso), que se desgastam ou envelhecem, e uma forma dinheiro (valor de troca,) que não o faz, deve ser corrigida (Harvey, 2014: 49).

Ou seja, Harvey retoma a contradição "entre o dinheiro como medida de valor e o dinheiro como meio de circulação" (EI: 292; EM: 295: EB: 383), exposta de modo cuidadoso em sua obra principal, mas, ao invés de pensar numa superação conjunta dessas funções o que significa a superação da própria forma do dinheiro e da mercadoria --, propõe algum tipo de medida reformista imediata pautada no controle do dinheiro e de seu desdobramento creditício. ${ }^{27} \mathrm{O}$ que ocorre é que a própria crítica radical da forma mercadoria, do dinheiro, do capital e do trabalho é relegada às grandes alturas de uma reflexão teórica e acaba banida para um futuro distante inalcançável. Como já apontado por Marx em sua crítica de um discípulo de Proudhon, é evidente que "o mal da sociedade burguesa não pode ser remediado por meio de 'transformações' dos bancos ou da fundação de um 'sistema monetário’ racional” (2011: 85).

Isso é ainda mais óbvio quando se analisa a abordagem de Harvey sobre o problema da falta de um lastro material para o sistema monetário. Para ele, a contradição presente na forma dinheiro era "mais fácil de entender quando o sistema da política monetária tinha uma clara base metálica" (2011: 97). Para ele, o capitalismo de Bretton Woods "funcionou bem, enquanto os EUA se abstiveram do uso de seu poder de imprimir dólares para atender apenas a seus interesses" (2011: 35), mas o fim do padrão dólar-ouro significou uma vertiginosa ampliação das instabilidades, pois, "o capitalismo mundial simplesmente não pode funcionar sem algum tipo de moeda de reserva estável - e esta é a dificuldade que o sistema monetário internacional tem enfrentado desde o início da década de 1970" (EI: 249; EM: 254; EB: 333). Esta é, novamente, uma interpretação que ele obtém apoiandose teoricamente em Suzanne de Brunhoff, uma defensora do fundamento metálico das moedas.

Sem dúvida, a moeda metálica garantia um nível de estabilidade maior ao conjunto do sistema monetário e mantinha sob certos limites o sistema de crédito - o que não significa que dava estabilidade ao capitalismo. O problema é que não há como retornar a um padrão de dinheiro-mercadoria, pois temos hoje os problemas básicos de financiamento de toda a estrutura burguesa - endividada até a alma, seja na esfera pública ou privada, incapaz de ser convertida em qualquer mercadoria disponível. Além disso, o patamar de produção alcançado pela sociedade burguesa é tal que impede qualquer espelhamento material de sua riqueza abstrata. O capitalismo se tornou tão produtivo e rico - a superacumulação deixou de ser cíclica e se tornou crônica - que qualquer base material seria limitada demais para conter a riqueza em forma monetária. Isso significa também que o capitalismo já não funciona mais segundo seus fundamentos lógicos, os seus próprios termos, portanto, precisa ser superado, não reformado. David Harvey, como enxerga o problema de uma perspectiva temporária, cíclica, ainda pode confiar na possibilidade de um sistema alternativo ou na proposta de reforma do sistema monetário visando reprimir a especulação. ${ }^{28}$

Numa época de desconfiança generalizada em relação ao sistema financeiro, de censura superficial aos bancos e à especulação, as propostas de Silvio Gesell ressuscitadas por Harvey podem parecer oportuna, mas elas revelam a limitação dos horizontes da critica 
social contemporânea, pois mesmo grandes autores com relevantes obras podem reduzir a crítica do capitalismo a um problema monetário.

\section{BIBLIOGRAPHY}

Althusser, Louis. Análise crítica da teoria marxista. Rio de Janeiro: Zahar, 1967.

Botelho, Maurilio Lima. Crise do capitalismo e "mundo do trabalho" em David Harvey. In: Revista Sinal de Menos, no. 10, 2014. Disponível em: https://dl.dropboxusercontent.com/u/65249844/ SINAL_DE_MENOS_10.pdf. Acesso em nov. 2014a.

. Teoria da Crise em David Harvey. In: Revista Continentes (UFRRJ), ano 3, n.4, 2014, p. 66-111. Disponível em: http://r1.ufrrj.br/revistaconti/pdfs/4/ART4.pdf. Acesso em nov. 2014b. Brunhoff, Suzanne de. A moeda em Marx. Rio de Janeiro: Paz e Terra, 1978.

Eichengreen, Barry. A globalização do capital. Uma história do sistema monetário internacional. São Paulo, Ed. 34, 2000.

Fausto, Ruy. Marx: lógica e política. Investigações para uma reconstituição do sentido da dialética. Tomo I. São Paulo: Brasiliense, 1987.

. Dialética Marxista, Dialética Hegeliana: a produção capitalista como circulação simples. São Paulo: Paz e Terra, 1997.

Harvey, David. Los limites del capitalismo y la teoria marxista. Cidade do México: Fondo de Cultura Económica, 1990. [EM].

. Spaces of neoliberalization: towards a theory of uneven geographical development.

Munique: Franz Steiner Verlag, 2005.

The Limits of Capital. London: Verso, 2006. [EI].

O Enigma do Capital e as Crises do Capitalismo. São Paulo: Boitempo, 2011.

- A urbanização e as crises. In: Pós. Revista do Programa de Pós-Graduação em Arquitetura e Urbanismo da FAUUSP, v. 19, no. 32, dez. 2012, p. 10-24.

. A importância da imaginação pós-capitalista. Disponível em: http:// www.revistaforum.com.br/blog/2013/08/david-harvey-importancia-da-imaginacao-poscapitalista/. Acesso em dez. 2013.

. Os limites do capital. São Paulo: Boitempo, 2013. [EB].

Diecisiete contradicciones y el fin del capitalismo. Quito: Editorial IAEN, 2014.

Jameson, Fredric. A cultura do dinheiro - ensaios sobre a globalização. Vozes: Petrópolis, 2002.

Kurz, Robert. A economia política do anti-semitismo. Disponível em: http://obeco.planetaclix.pt/ rkurz164.htm. Acesso em nov. 2013.

. Dinheiro sem valor - linhas gerais para uma transformação da crítica da economia política. Lisboa: Antígona, 2014. 
Marx, Karl. o Capital - crítica da economia política. Livro I: O processo de produção do capital (tomo I) São Paulo: Nova Cultural, 1985a.

. O Capital - crítica da economia política. Livro II: O processo de circulação do capital (tomo III) São Paulo: Nova Cultural, 1985b. . Para a crítica da economia política. São Paulo: Nova Cultural, 1986

Grundrisse: Manuscritos econômicos de 1857-1858. Esboços da crítica da economia política. São Paulo: Boitempo, 2011.

Mollo, Maria de Lourdes Rollemberg. A relação entre moeda e valor em Marx. In: Revista de Economia Política, vol. 11, no. 2 (42), abr-jun 1991, p. 40-59.

Paulani, Leda Maria. Sobre dinheiro e valor: uma crítica às posições de Brunhoff e Mollo. In: Revista de Economia Política, vol. 14, no. 3 (55), jul-set 1994, p. 67-77.

. Autonomização das formas sociais e crise. In: Crítica Marxista, no. 29, 2009, p. 25-31.

Reichelt, Helmut. Sobre a estrutura lógica do conceito de capital em Karl Marx. Campinas: Ed.

Unicamp, 2013.

Rotta, Tomas Nielsen. Dinheiro inconversível, derivativos financeiros e capital fictício: a moderna lógica das formas. Dissertação (Mestrado). Universidade de São Paulo, 2008, 204 pp.

\section{NOTES}

1. Num artigo em que registra sua "dívida com The Limits of Capital", Jameson discute a relação estabelecida por Harvey entre propriedade da terra e capital fictício, mas o foco de sua reflexão é a abstração nas relações contemporâneas, cuja origem é "a forma monetária - a origem fundamental de toda abstração" (2002: 173).

2. "Assim, como observa Harvey, o crédito parece harmonizar e resolver as contradições do capitalismo, mas ele, e aqui Harvey cita o Marx dos Grundrisse 'suspende as barreiras à realização do capital, somente porque as eleva à sua forma mais geral”' (Paulani: 2009: 27-28).

3. Conforme indicamos em artigo anterior (Botelho, 2014b), a edição brasileira de Os Limites de Capital tem problemas graves de tradução que comprometem a sua compreensão. Sempre que fizermos referência a essa obra mais importante de Harvey, faremos tradução do original em inglês, mas indicaremos ainda a mesma passagem na edição mexicana e brasileira, indicadas respectivamente como EI, EM e EB, seguidas das páginas. Nesse primeiro trecho citado tentamos ser ao máximo fiel ao texto original de Harvey, inclusive nas partes em que usa Marx, pois há diferenças textuais entre a versão que utiliza e as traduções brasileiras de O Capital (1985a: 92).

4. Ainda que isso não possa ser interpretado como uma teoria da verdade ou do reflexo, isto é, como adequatio rei et intellectum.

5. “As mercadorias não têm um valor individual, mas apenas um preço individual. Os próprios preços, porém, têm de se apresentar de imediato sob a forma do valor, exprimir um valor real, concretamente, a respectiva quota-parte na massa real do valor de toda a sociedade que a mercadoria pode alcançar a título individual aquando da sua venda. Por isso, o dinheiro que representa e realiza os preços não só tem de ser, ele próprio, mercadoria, como também, contrariamente a todas as mercadorias, valor individual em termos imediatos - não em cada exercício da sua função (por exemplo, nos pagamentos quotidianos), mas em princípio" (Kurz, 2014: 197).

6. Em Harvey essa difícil relação o leva a diferenciar, para explicar as contradições entre valor e preço nas mercadorias tomadas individualmente, o tempo de trabalho socialmente incorporado 
numa mercadoria do tempo de trabalho socialmente necessário que em média ela pode ser trocada: "O antagonismo entre as formas relativa e equivalente de valor é preservado dentro da forma monetária porque a mercadoria-dinheiro agora personifica duas medidas de valor: o tempo de trabalho socialmente necessário que incorpora e o tempo de trabalho socialmente necessário pelo qual, em geral, pode ser trocada." (EI:242; EM: 247; EB: 325). Isso não faz sentido algum, na medida em que ele cinde o conceito em uma dimensão individual e social, num sentido inverso ao realizado por Marx, porque este o introduz, na quarta página de 0 Capital, exatamente para demonstrar a pressuposição social de toda produção individual (o tempo de trabalho é individual mas só faz sentido quando sua magnitude é socialmente necessária, não correspondendo a um dispêndio inútil e moroso). Toda mercadoria pode possuir diversos valores de troca, na medida em que se espelha em diversas outras formas equivalentes de mercadoria, assim como pode possuir diversos preços de acordo com a moeda que a espelha (preço em ouro, em dólar, em real etc.), mas possui apenas uma medida de valor correspondente a seu quantum em tempo de trabalho.

7. Comentamos essa condição para a crise e seu desdobramento real na apresentação que fizemos sobre a teoria da crise em David Harvey (Botelho, 2014b).

8. Sobre isso ver o último livro de Robert Kurz (2014), principalmente os capítulos 4 e 5 . Essa passagem de Marx, em nota de rodapé de 0 Capital, onde comenta sobre o papel do dinheiro como "figura alienada de todas as coisas" entre os fenícios já traz essa possibilidade de interpretação, pois antes de concluir citando Shakespeare e Sófocles, ele salienta que as virgens que se entregavam por dinheiro na festa da deusa do amor ofertavam a moeda a essa deusa (1985a: 112). 9. "Moeda de crédito têm a sua origem em letras de câmbio e notas de crédito contratadas privadamente e que adquirem a forma social de dinheiro logo que começam a circular como meio de pagamento" (EI: 245; EM: 250; EB: 328).

10. “... dado que num país é o ouro, e em outro é a prata que desempenha essa função, no mercado mundial é válida uma dupla medida de valor", escreve Marx em 1857 (1986: 108). Em O Capital, volta a repetir o papel universal do bimetalismo: "no mercado mundial domina dupla medida de valor, o ouro e a prata" (1985a: 261). Contudo, pouco depois da publicação da primeira edição dessa obra, um movimento geral de adoção do ouro relegou a prata a um plano menor no mercado mundial, pois as principais potências seguiram a Inglaterra em seu padrão monetário. Sobre isso ver Einchengreen (2000: 42-44).

11. A tradução brasileira comete aqui grave erro invertendo o sentido de toda a reflexão de Harvey sobre os bancos, porque tornam os capitalistas individuais os verdadeiros fiadores dos bancos: “... quando os bancos emitem suas próprias notas ou permitem que os cheques se inspirem nelas, eles substituem sua própria garantia por aquela de inúmeros capitalistas individuais" (EB: 330).

12. "O resultado, porém, é que 'o banco central é o eixo do sistema de crédito' e 'a reserva de metal, por sua vez, é o eixo do banco’. Despojado de sua ligação direta com a mercadoria-dinheiro implicada na expressão 'reserva de metal', isto significa que o banco central regula necessariamente o fluxo de crédito na tentativa de preservar a qualidade de dinheiro" (EI: 280; EM: 284; EB: 369).

13. Daqui poderia surgir uma importante discussão sobre a lógica empregada por Marx para expor e criticar a sociedade burguesa: de um lado, é possível concordar com a interpretação neoclássica de que o mercado é apenas a instituição mediadora de riqueza (neutralidade do dinheiro), porém pode-se apontar também a correção da visão keynesiana de que vivemos numa economia monetária (portanto, o dinheiro é reserva de valor, tem um poder especial). A divergência entre essas teorias contraditórias não pode ser suprimida pela opção de uma ou outra, mas da aceitação, confronto e demonstração de limitação de ambas. "Portanto, é como se o capitalismo tivesse duas aparências: uma em que o dinheiro é supérfluo, como fazem os autores neoclássicos, e outra em que o dinheiro é 'tudo', como fazem os pós-keynesianos" (Rotta, 2008: 
88). Para ser mais preciso, a aparência do capitalismo é que o dinheiro é apenas meio de circulação (neutro), sua essência nos indica que o dinheiro tem um poder especial. Essência e aparência são ambas partes da mesma realidade efetiva, não são mais ou menos verdadeiras que a outra.

14. “... a maioria dos bancos centrais é separada dos outros bancos através da garantia de certos privilégios monopolistas. Livre da necessidade de competir, o banco central pode dedicar-se a sua única tarefa: defender a qualidade do dinheiro nacional. Para realizar esta função, o banco central torna-se o guardião das reservas de ouro do país. Isto lhe dá o poder de rejeitar a moeda bancária 'ruim' ao negar-lhe a conversibilidade em moeda do banco central, que é o único tipo de dinheiro que é livremente conversível em ouro" (EI: 248; EM: 253; EB: 332).

15. Aqui há um pequeno deslize conceitual da parte de Harvey: não sendo o resultado de trabalho materializado, mas pura ficção monetária, a moeda de crédito não possui valor, mas unicamente preço, com o que pode servir como meio de pagamento. Esse problema não tem importância do ponto de vista da superficialidade da esfera das trocas ou da posição atomizada dos agentes em concorrência no mercado. Contudo, para uma crítica radical da sociedade capitalista, essa diferença conceitual é essencial para compreender porque a ficcionalização promovida por um sistema de crédito extremamente evoluído é incapaz de fazer o capitalismo se reproduzir ampliadamente - a objetividade da totalidade da estrutura burguesa não pode ser enganada por esta ficção.

16. Segundo a interpretação rigorosa de Ruy Fausto, a seção I de $O$ Capital aborda a circulação simples enquanto aparência do sistema capitalista, que tem uma primeira negação ma seção II desse livro, mas ainda assim insuficiente porque não põe o problema da reprodução, algo que Marx só faz na passagem da seção VI à seção VII de O Capital, quando Marx trata da "interversão das leis da propriedade da produção de mercadorias em lei da apropriação capitalista" (Fausto, 1987:191-192). Embora comumente traduzido como “conversão", a expressão utilizada por Marx seria melhor tratada como "interversão", porque um pólo mantém-se negado no seu outro e não apenas transforma-se em outro. Em linhas gerais a ortodoxia marxista entendeu essa primeira seção como um preâmbulo histórico sobre as relações de troca para depois tratar do capitalismo propriamente dito.

17. Ou seja, é a aparência necessária mas não o modo essencial como esse sistema funciona, pois essa aparência, embora evidente e cotidiana, é negada pela essência real de uma economia que se baseia na exploração de trabalho alheio, portanto na apropriação de valores excedentes da mercadoria força de trabalho. Sobre isso, ver o livro de Ruy Fausto que trata dessa temática (1997).

18. "Mas também o sistema escravagista - à medida que é a forma dominante do trabalho produtivo na agricultura, manufatura, navegação etc., como nos Estados desenvolvidos da Grécia e em Roma - mantém um elemento da economia natural. o próprio mercado de escravos recebe constantemente oferta de sua mercadoria fora de trabalho por meio de guerras, piratarias etc., e esse roubo, por sua parte, não é mediado por um processo de circulação, mas constitui apropriação in natura de força de trabalho alheia por meio da coerção física direta" (Marx, 1985b: 349). Isso, evidentemente, está em contradição com a citação anterior de Marx que indicava o dinheiro, mesmo em situações pré-modernas, como a "figura alienada de todas as coisas", já que o dinheiro nunca foi universal a não ser na modernidade capitalista.

19. Diferente de Brunhoff, contudo, Rosdolsky nunca parte para uma interpretação propriamente dita da obra de Marx, apenas fazendo reconstituição de sua estrutura teórica e esclarecendo sua terminologia lógica, isso faz com que seu impacto seja menor na leitura de Harvey e não sirva como contrapeso ao estruturalismo de Brunhoff. "Uma das debilidades do [livro de Rosdolsky] consiste especialmente no fato de apenas chamar a atenção para o uso das categorias hegelianas e, no mesmo fôlego, reproduzir quase sem comentários passagens inteiras que se distinguem por suas formulações de cunho altamente especulativo e, por isso mesmo, extremamente carentes de 
interpretação (Reichelt, 2013: 24). Na verdade, não deixa de ser uma ingenuidade citar esses dois autores ao mesmo tempo como referência para a análise do dinheiro, porque compreendem abordagens marxistas completamente divergentes -- que poderiam ser chamadas, grosso modo, de uma posição hegeliana e dialética (Rosdolsky) e uma posição althusseriana e anti-dialética (Brunhoff).

20. O livro de Brunhoff foi alvo de um debate entre Leda Maria Paulani (1994) e Maria de Lourdes Rollemberg Mollo (1991) em torno do papel da dialética na teoria do dinheiro de Marx.

21. Como se sabe, segundo Althusser, Marx fundou uma ciência nova, a "ciência da história das ‘formações sociais"'. Assim como Tales de Mileto inaugurara a ciência matemática e Galileu a física, Marx abriu o "continente da história” para o conhecimento científico (1967: 8).

22. Para Brunhoff o tipo de abstração desenvolvido por Marx no início de 0 Capital é puramente lógica, uma "boa abstração" que conduz o "estudo" às formas abstratas de uma "teoria geral" (1978: 17). Marx, contudo, deixa muito evidente que essa redução da complexidade social à natureza abstrata das mercadorias e do dinheiro não é puramente lógica: "Essa redução aparece como uma abstração, mas é uma abstração que se realiza todos os dias no processo de produção social. A redução de todas as mercadorias em tempo de trabalho não é uma abstração maior nem ao mesmo tempo menos real do que a redução em ar de todos os corpos orgânicos"(1986: 33).

23. "Não há na teoria marxista, por exemplo, algo como o trabalho abstrato por fora das múltipas atividades concretas de produção e intercâmbio que o geram, o concreto é, como Marx observou, uma concentração de determinações tão diferentes que nunca pode ser reduzido a uma mera manifestação particular do abstrato" (Harvey, 2005: 59). Ora, o caráter abstrato do dinheiro, levado ao extremo com a moeda de crédito e o capital fictício, que dispensa qualquer fundamento material, é a demonstração de que as abstrações se tornam reais na sociedade burguesa.

24. "O dinheiro representa, afinal, o valor de troca par excellence e, assim, se opõe a todas as outras mercadorias e seus valores de uso. $O$ dinheiro assume um poder independente e externo em relação à troca, porque, como o equivalente universal, é a própria encarnação do poder social. Este poder social, além disso, pode ser apropriado e utilizado por particulares. A importância disso precisa ser analisada aqui" (EI: 245; EM: 250; EB: 328)..

25. "É pois bem digno dos utopistas pequeno-burgueses querer a mercadoria sem querer o dinheiro, o capital industrial, mas não o capital a juros, o lucro e não o juro" (Marx, 1986: 201-202).

26. Ver quanto a isso nosso artigo que trata da visão de Harvey sobre as relações de trabalho e o peso dos salários na produção contemporânea (Botelho, 2014a).

27. A proposta de Silvio Gesell era de que todo meio de circulação sofresse uma desvalorização automática anual, incluindo aí os depósitos bancários. Isso obrigaria os indivíduos a se livrarem da moeda fazendo-a circular, comprando mercadorias ou investindo produtivamente (ou seja, comprando meios de produção). Aqueles que tivessem meios de circulação em suas mãos e não quisessem passar totalmente pela redução monetária deveriam pagar taxas. Em suma, ser proprietário do dinheiro seria uma desvantagem, impedindo a especulação e o entesouramento. A proposta de Gesell se insere não apenas na trajetória pequeno burguesa de um socialismo reformista amigo do trabalhador, e do capitalista produtivo contra o capitalista especulador, como ainda tem potenciais anti-semitas ao realizar uma critica exclusiva ao "parasita financista", histórica e culturalmente associado ao judeu. Isso não significa que Gesell fosse um anti-semita. Sobre isso ver Robert Kurz (2013).

28. Em uma nota de Os Limites do Capital, Harvey faz uma longa citação do economista Jürg Niehans, então seu colega na Universidade Johns Hopkins, em defesa da moeda mercadoria, pois esse seria o único tipo de dinheiro que "passou no teste da história nas economias de mercado". Em toda a história moderna teria sido feito o uso de moeda metálica como forma dominante de dinheiro, a não ser em alguns "interlúdios de guerra, revolução e crise financeira". Harvey conclui a nota indicando que, de um ponto de vista marxiano, o período pós-Bretton Woods seria 
“apenas outro interlúdio" (EI: 245; EM: 250; EB: 328). Resta saber como um período de mais de quarenta anos pode ser apenas um interlúdio histórico.

\section{ABSTRACTS}

O objetivo do artigo é expor a abordagem de David Harvey sobre o desenvolvimento lógico do dinheiro e da moeda, a partir da mercadoria, em sua interpretação da obra de Marx. Propomos, com isso, destacar as principais contribuições das obras de David Harvey, em particular Os Limites do Capital, para a compreensão da relação entre dinheiro e crédito, assim como problematizar alguns fundamentos teóricos em sua leitura.

This paper aims to present the David Harvey's approach to the logical development of money and currency, from marchandises, in its interpretation of Marx's work. We aim then to stress the main contributions of the work of David Harvey, in particular The Limits to Capital, for understanding the relationship between money and credit, as well as discussinf some theoretical background on his reading.

Cet article présente la démarche de David Harvey sur le développement logique de l'argent et de la monnaie - à partir de la marchandise - dans son interprétation de l'œuvre de Marx. Ainsi, cette article vise à souligner les principaux contributions de la pensée de Harvey, en particulier The limits to capital (2006 [1982]), pour comprendre les rapports entre l'argent et le crédit, ainsi qu'interroger quelques uns des fondements théoriques de l'auteur.

El objetivo del artículo es exponer el planteamiento de David Harvey sobre el desarrollo lógico del dinero y de la moneda, a partir de la mercancía, en su interpretación de la obra de Marx. Se propone, con eso, destacar las principales contribuciones de las obras de David Harvey, en particular los Límites del Capital para la comprensión de la relación entre dinero y crédito, así como problematizar algunos de los fundamentos teóricos de su lectura.

\section{INDEX}

Mots-clés: argent, monnaie, crédit, Harvey, Marx

Keywords: money, currency

Palabras claves: dinero, moneda, crédito

Palavras-chave: dinheiro, moeda, Marx.

\section{AUTHOR}

\section{MAURILIO LIMA BOTELHO}

Programa de Pós-Graduação em Geografia da Universidade Federal Rural do Rio de Janeiro (PPGGEO/UFRRJ). Email: mauralio@oi.com.br 